\title{
Nossos Colaboradores
}

\section{Marialice M. Pessoa}

Bacharel licenciada em Geografia e História, pela Faculdade Nacional de Filosofia; Professôra de História da I Filosofia do Instituto Técnico do Colégio Bennett e de Métodos de Pesquisa e de Relações Públicas da E.B.A.P. da Fundação Getúlio Varges. Professôra de Antropologia Cultural de Cursos da S.P.V.E.A. (Superintendência do Plano de Valorização Éconômica da Amazônia), em Belém, no Estado do Pará. Ministrou aulas de Português nos cursos do Instituto Brasil-Estados Unidos, além de ter sido Instrutora Visitante da mesma cadeira, no Universidade de Havana, e nas universidades norte-americanas, "Rutgers Univiversity" e "University of Pensylvania". Lecionou Antropologia no Curso Intensivo do Serviço Social Rural e foi também, Professôra Visi- tente de Antropologia Brasileira no "Baldwin Wallace College", e ainda na "University of Redlands".

Colaborou em diversas conferências e seminários, organizando programas e apresentando teses sôbre Antropologia e Pesquisas Cientificas realizadas por organismos oficiais brasileiros e norteamericanos.

Foi bolsista do Estado de São Paulo e da U.S.A.I.D., com curso de PósGraduação em Administração Pública na "University of Southern California". Articulista da Revista do Museu Paulista (Estado de São Paulo - Brasil) e Chefe do Grupo de Pesquisadores para a confecção dos Cadernos para o Curso de Planejamento Regional, onde já apresentou mais de 20 cadernos, versando em tôrno dos mais variados temas, dentre os quais se contam um "Plano Decenal para o Congo Belga" e um "Plano para o Carvão Nacional". 